\title{
"Superstición": engaño, mala fortuna y superchería en un nuevo cuento rescatado de Emilia Pardo Bazán
}

\author{
Ma del Mar Novo Díaz \\ marimarnovo@gmail.com
}

(recibido xaneiro/2016, revisado febreiro/2016)

RESUMEN: En el presente trabajo se aborda el estudio de un nuevo cuento de Emilia Pardo Bazán, no registrado hasta el momento: "Superstición". Fue publicado en La Unión Ilustrada de Málaga el 9 de abril de 1911. Este cuento breve, depurado y con una historia redonda, muestra el excelente ingenio y elaboración de los relatos de la escritora coruñesa.

PALABRAS CLAVE: Cuento, Emilia Pardo Bazán, "Superstición", no registrado, La Unión Ilustrada, Málaga, 1911.

ABSTRACT: In the present work there is tackled the study of a new short story of Emilia Pardo Bazán non registered up the moment: "Superstición". It was published in La Unión lustrada of Málaga on April 9, 1911. This story short, refined and with a round history, it shows the excelent ingenuity and elaboration of the stories of the writer of Coruña.

KEY WORDS: Short story, Emilia Pardo Bazán, "Superstición", unregistered, La Unión Ilustrada, Málaga, 1911.

Una nueva colaboración no registrada, hasta el momento, de doña Emilia Pardo Bazán nos lleva a afirmar que todavía quedan textos e historias nuevas por sacar a la luz de la escritora herculina. En este caso presentamos una aparecida en Málaga.

En La Unión Ilustrada de Málaga, semanario gráfico de la misma empresa que La Unión Mercantil, encontramos el cuento "Superstición". Este semanario aparece el 5 de septiembre de 1909 en la ciudad andaluza con un formato muy similar a Nuevo Mundo, Blanco y Negro, Mundo Gráfico.

Su director es Pedro Alfaro Gutiérrez que, desde 1914, dirigirá conjuntamente La Unión Mercantil y La Unión Ilustrada.

El 9 de abril de 1911 aparece la primera colaboración de la escritora gallega en dicha revista: "Superstición". Probablemente el cuento se encuentre publicado con anterioridad en otra cabecera. Si nos fijamos, aparece firmado por Emilia Pardo Bazán. Como ya es sabido, en 1908 recibe el título de Condesa de Pardo Bazán de manos de Alfonso XIII, parecería lógico encontrar por tanto en aquella fecha la conocida firma con que desde tres años atrás rubrica sus textos: LA CONDESA DE PARDO BAZÁN.

Hasta el 9 de noviembre de 1913 no encontramos otra publicación de la escritora coruñesa en La Unión Ilustrada: "Dioses". En esta ocasión, sí firma como Condesa de Pardo Bazán. No son demasiados los cuentos publicados en La Unión I/ustrada de Málaga, se reducen a siete, incluyendo el que rescatamos en este trabajo: "La caja de oro" (29/03/1914), "Los cabellos" (7/01/1915), "Las cerezas" (22/08/1915), "El encaje roto" (17/10/1915) y "La sombra" (14/06/1917). Podemos y debemos pensar que no es ésta una cabecera en la que doña Emilia ofrezca primicias. Desde 1911 hasta 1931 aparece citada en varias ocasiones.

El 6 de mayo de 1923, a punto de cumplirse dos años del fallecimiento de la autora de Cuentos de Marineda, Antonio Gascón, con motivo de la edición que la Editorial Atlántida hace de Cuentos de mi tierra, escribe en La Unión Ilustrada: 
Se ha dicho muchas veces que la mejor obra de doña Emilia eran los cuentos. Esto, que no resta mérito alguno de los demás géneros literarios cultivados por tan insigne dama, se comprueba una vez más con la lectura de la obra póstuma CUENTOS DE MI TIERRA.

Son las narraciones que componen este tomo como los vasos de buen vino, que se trasiegan uno tras otro, animado el bebedor por el buen gusto que le dejaron los anteriores, hasta que, sin darse cuenta, termina con la botella. Lo mismo sucede con estos cuentos de la Condesa de Pardo Bazán: se leen de un tirón, uno tras otro, animado el lector por el placer que le produjeron los anteriores, hasta que, sin darse cuenta, llega al último, lamentando que se haya concluido el libro y no pueda continuar la lectura (p. 12).

En el tercer tomo de La literatura francesa moderna, doña Emilia escribe: "El cuento será, si se quiere, un subgénero, del cual apenas tratan los críticos: pero no todos los grandes novelistas son capaces de formar con maestría un cuento" (1914: 153). Con estas palabras se refería la escritora herculina al cuento, género del que ella es la gran maestra de los siglos XIX y XX.

El cuento exhumado en este trabajo condensa la esencia de esa perfección a la hora de elaborarlo, despertando nuestro interés desde las primeras palabras, como era su propósito. En una columna escasa, consigue presentarnos una historia redonda, breve, depurada, reducida a lo mínimo, a lo imprescindible, y con el golpe de efecto certero y necesario en todo buen cuento que se precie de serlo.

Ya desde el principio nos encontramos con un presagio de lo que va a suceder, un título con clara intención connotativa: "Superstición", que prepara el terreno para el trágico desenlace seguido de un:

Ella se lo había dicho mil veces.

-Si llegamos a no estar juntos a las doce de la noche del día último del año... será que ese año la fatalidad quiere que se acabe nuestro amor.

Adelantando elementos de la trama, consigue poner sobre aviso al lector anunciando lo que va a suceder.

Predomina un ambiente de fatalismo, tristeza, fracaso y engaño, estamos ante un amor abocado a la fatalidad desde la primera frase. El narrador omnisciente deja entrever sus sentimientos de simpatía y afecto hacia la dama innominada: "Ella, devorando las lágrimas, murmuró lentamente". Para referirse al caballero, también sin nombre, utiliza calificativos despectivos: "respondió él, cobarde y mentiroso".

Los párrafos son cortos, el más extenso lo conforma el relato por parte del narrador del proceso del engaño y su plan para no ser descubierto: "retirarse a las once y media, tomar un coche y ser exacto"; también en este párrafo se repite con insistencia la palabra "superstición" que da título al cuento. Dicha superstición nos lleva a pensar en el mal fario del número trece que precede a las uvas: "trece granos él, trece granos ella", esto no obedece a un despiste de la autora, es un mal augurio de lo que acontecerá. Como es sabido, son doce las uvas que comemos para celebrar el Fin de Año. Gedeón (Madrid, 14 de enero de 1897, nº 62, p. 3), se hace eco de esta costumbre al recoger un fragmento de El Veloz sport: órgano del ciclismo español y extranjero, de Madrid (cabecera madrileña que no he logrado localizar), donde aseveran: "Es costumbre madrileña comer doce uvas al dar las doce horas en el reloj que separa el año saliente del entrante". El 1 de enero de 1894 en El Imparcial (n 9565, p. 3), encontramos en un breve artículo titulado "Uvas Bienhechoras" la primera referencia a estas uvas, que remite a que "es una costumbre importada de Francia"; no explicita el número de uvas pero afirma que se comen el 31 de diciembre al toque de la primera campanada de las doce de la noche.

Si tuviésemos que quedarnos con una serie de palabras que permitan resumir el cuento estas podrían ser: "superstición", "uvas", "trece", "once y media", "rubia", "nunca", "acabar". El cuento muestra el triunfo de lo opulento, lo falso e interesado frente a lo natural, sincero y verdadero. Racimos de uvas en cucuruchos de papel que son repartidas entre los dos amantes, besos que muestran el triunfo del amor; frente a esto, tenemos uvas en bandejas de plata que cortan sirvientas con tijeras brillantes, una mujer rubia, tentadora, "de peinado a lo arcángel" ${ }^{\prime 1}$.

El galán es consciente de que pierde su amor, pero no es capaz de marchar, se relata el fin de ese amor: "Los minutos volaban. Ya las doce menos cuarto... las doce en punto... ¡Se acabó!

${ }^{1}$ Hace referencia al pelo totalmente recogido mediante trenzas. Son varias las imágenes de arcángeles representados con este recogido: San Miguel, San Gabriel o San Rafael. 
La única solución es la mentira, por segunda vez miente: "-Reloj atrasado... Simones que no había...". Para él no es una novedad, ya lo había hecho antes, cuando responde a la niña rubia de peinado a lo arcángel que nunca había comido las uvas a las doce de la noche.

El último párrafo es el colofón perfecto para la historia. El amor se acaba, las uvas no son las culpables, sí lo fue la falta de decisión del amante. Si la hubiese querido como la amaba antes eso no habría pasado, él hubiese ido a su encuentro. De ahí la frase lapidaria de ella: "Lo que muere fuera, es que antes lo mataron dentro".

Se nos ofrece una visión trágica del amor. Ángeles Quesada en El amor en los cuentos de Emilia Pardo Bazán nos refiere:

[hay] ciento ochenta cuentos en los que la problemática de pareja -entendiendo por tal tanto la relación amorosa como la contractual- ocupa el interés central del relato, bien sea para mostrar el dolor del amor, bien para cantar las alegrías del goce emocional.

Así puede observarse que se muestra remisa a darle a las relaciones de pareja -al amor en suma- nada más que breves momentos de felicidad, seguidos del desengaño y la tristeza: que mantiene una visión bastante pesimista del ideal burgués de pareja² (2005, pp.15-16 y 20)

En este caso lo que se ofrece al lector es la historia de dos seres anónimos: él y ella, cuya relación está marcada desde el principio por la llamada superstición. Él está seguro de que ella lo espera y juntos rompen año tras año con el mal auspicio que no se cumple con "los corazones prendados de veras".

No queda claro el tipo de relación que mantiene la pareja, se habla de "nido" pero no es su esposa, de ser así hubiese asistido a la fiesta con su marido. Es la mujer la que rompe la relación, una mujer con carácter y fuerte pero a la vez resignada ante la desdicha anticipada desde el mismo título. Se podría poner en relación con las dos mujeres abandonadas de "Instintivo" y "Comedia" que terminan suicidándose ante el abandono. ${ }^{3}$ En este caso no se aclara su final, la reacción ante la ausencia y posterior mentira del hombre la lleva a romper la relación justificando esta ruptura con la muerte del amor en el interior del amado. No es el augurio lo que mata el amor, no son "las uvas no comidas", es la ausencia del amado al acabarse el amor en su alma.

Quien rompe el compromiso es la mujer, como ocurre en "La novia fiel" o "Vocación". El hombre, con mentiras, pretende seguir con la misma situación. Miente doblemente a "ella", y a la muchacha peinada "a lo arcángel".

A continuación transcribimos el cuento tal y como apareció en la cabecera malagueña con la única excepción del añadido de una coma en: "Cuando a la una menos cuarto, llegó al lado de su amiga, mintió nuevamente".

\footnotetext{
${ }^{2}$ Quesada Novás, Ángeles (2005). El amor en los cuentos de Emilia Pardo Bazán. Alicante. Publicaciones de la Universidad de Alicante.

${ }_{3}^{3}$ González Herrán, José Manuel (2011). Emilia Pardo Bazán. Cuentos dispersos I (1865-1910) y II (1911-1921), Madrid, Fundación José Antonio de Castro. Biblioteca Castro. Pp. 215-218 (I) y 215-220 (II).
} 


\section{EN LA MUERTE DE LA INSIGNE POETISA CAROIINA CORONADO}

...no hay vida ninguna Que no arrostre el furor de una corriente, Y si nos ha de ahogar jay! la del llanto, La del mar es mejor... ino amarga tanto! Carolina Coromago.

¡Al fin cesó, poetisa, tu trágica odisea! Al fin triunfante subes al mundo de la luz! Al mundo en que fijabas el vuelo de tu idea, Cuando al trepar el Gólgota, tras lucha gigantea, Llevabas en tu mano la lira como cruz.

La lira que tradujo tus cantos pasionales, Tus místicòs amores, tu sólida piedad, De tu sensible pecho las ánsias inmortales, De tu gigante espíritu los nobles ideales, Tus puros entusiasmos, tu ingénita bondad.

Llenó el pasado siglo tu númen prepotente: Los vates, admirados, de tí fueron en pos; La gleria iluminaba tu soñadora mente.. De-las selectas almas el sello refulgente, Como inflamado Sínai, puso en tu frente Dios.

El Genio esplendoroso te acarició en la cuna, Nimbando de aureolas tu hermosa juventud: Querida y respetada te viste cual ninguna; Mas luego joh gran poetisa! voluble la Fortuna Santificó tu vida, probando tu virtud.

$$
\text { - }
$$

Cayeron deshojadas de tu ilusión las flores, De mágico perfume, de espléndido matiz, Dejando en tus entrañas abrojos punzadores... ¡La despiadada Muerte, hiriendo tus amores, Hundió en horrible noche tu corazón feliz!

En tu dolor eterno, buscaste el ostracismo, Y el Tajo, con tus lágrimas, sus ondas aumentó. ¡Callaste!... mas tu acento, con noble patriotismo, Cuando sufrió la Patria terrible cataclismo, Con trenos melancólicos, viril se levsntó.

- Cisne de Almendralejo, dulcísima cantora! Si un infinito duelo tu voz pudo apagar,

Tu espíritu sublime, que en las alturas mora, Cual ráfaga divina de lumbre bienhechora, La prosa de este siglo descienda á idealizar.

Descienda como lluvia de efluvios celestiales, Y ahuyente compasivo las sombras del error; Propague por el mundo grandiosos ideales, Eleve el sentimiento con ánsias inmortales, Y oponga á los rencores el aura del amor.

\section{Superstición}

Ella se lo habia dicho mil veces.

- Si llegamos á no estar juntos á las doce de la noche del día último del año... será que ese año la fatalidad quiere que se acabe nuestro amor.

Y él concurría exactamente todos los años á la hora sagrada, llevando, en un cucurucho de papel, un racimo de uvas que se comían concienzudamente los dos, trece granos él, trece granos ella. Después, en los labios se borraba el sabor de la fruta con otro sabor más fuerte y triunfante.

Llegó un año en que él aceptó una invitación para una fiesta en la cual, precisamente, á las doce, habían de comerse las uvas, servidas en bandejas de plata, por preciosas muchachas que con tijerillas brillantes desracimaban graciosamente el gajo y se lo presentaban á los convidados, riendo. El sabía que ella le esperaba, para acatar juntos 1 a superstición, cara á los corazones prendados de veras. Y formó el propósito de retirarse á las once y media, tomar un coche y ser exacto.

A las once y media estaba la fiesta en su mayor esplendor; una rubia de peinado à lo arcángel, se acercó à él y le comprometió para "las uvas", ofreciéndose á ser su proveedora.

- jNo ha comido usted nunca las uvas á las doce?-preguntó la niña.

- Nunca-respondió él, cobarde y mentiroso.

-Pues las comeremos juntos. ¡Dicen que trae una suerte atroz, si el compañero las come por vez primera!

El sentía que pasaba el tiempo; adivinaba la congoja de la que aguardaba allá, en el nido; y, sin embargo, no tenía resolución para irse. Los minutos volaban. Ya las doce menos cuarto... las doce en punto... 'Se acabó!

Cuando, á la una menos cuarto llegó al lado de su amiga, mintió nuevamente.

-Reloj atrasado... Simones que no había..

Ella, devorando las lágrimas, murmuró lentamente:

- Este año se acaba nuestro amor. Pero se acaba, no porque no hayamos comido unas uvas, á un toque de reloj, sino porque se habrá acabado en tu alma. Si no se hubiese acabado. hubieses venido. Lo que muere fucra, es que antes lo mataron dentro.

Emilia Pardo Bazán.

Se necesitan corresponsales fotográficos en todas partes.

Dirigirse al Administrador de esta Revista. Marqués, 5, Málaga. 


\section{Superstición}

Ella se lo había dicho mil veces.

-Si llegamos a no estar juntos a las doce de la noche del día último del año... será que ese año la fatalidad quiere que se acabe nuestro amor.

Y él concurría exactamente todos los años a la hora sagrada, Ilevando, en un cucurucho de papel, un racimo de uvas que se comían concienzudamente los dos, trece granos él, trece granos ella. Después, en los labios se borraba el sabor de la fruta con otro sabor más fuerte y triunfante.

Llegó un año en que él aceptó una invitación para una fiesta en la cual, precisamente, a las doce, habían de comerse las uvas, servidas en bandejas de plata, por preciosas muchachas que con tijerillas brillantes desracimaban graciosamente el gajo y se lo presentaban a los convidados, riendo. Él sabía que ella le esperaba, para acatar juntos la superstición, cara a los corazones prendados de veras. Y formó el propósito de retirarse a las once y media, tomar un coche y ser exacto.

A las once y media estaba la fiesta en su mayor esplendor; una rubia de peinado a lo arcángel, se acercó a él y le comprometió para «las uvas», ofreciéndose a ser su proveedora.

- ¿No ha comido usted nunca las uvas a las doce? -preguntó la niña.

-Nunca -respondió él, cobarde y mentiroso.

-Pues las comeremos juntos. ¡Dicen que trae una suerte atroz, si el compañero las come por vez primera!

Él sentía que pasaba el tiempo; adivinaba la congoja de la que aguardaba allá, en el nido; y, sin embargo, no tenía resolución para irse. Los minutos volaban. Y a las doce menos cuarto... las doce en punto... ¡Se acabó!

Cuando, a la una menos cuarto, llegó al lado de su amiga, mintió nuevamente:

-Reloj atrasado... Simones que no había...

Ella, devorando las lágrimas, murmuró lentamente:

-Este año se acaba nuestro amor. Pero se acaba, no porque no hayamos comido las uvas, a un toque de reloj, sino porque se habrá acabado en tu alma. Si no se hubiese acabado... hubieses venido. Lo que muere fuera, es que antes lo mataron dentro.

EMILIA PARDO BAZÁN.

La Unión Ilustrada. Revista artístico- literaria (9 de abril de 1911): Domingo, núm. 82, p.12. 


\section{BIBLIOGRAFÍA}

Gedeón: semanario satírico (14 de enero de 1897): Madrid, núm. 62, p. 3.

El Imparcial. Diario liberal (1 de enero de 1894): Madrid, núm 9.565, p. 3.

Pardo Bazán, Emilia (1914). La Literatura Francesa Moderna III. El Naturalismo. Obras Completas. Madrid. Renacimiento.

La Unión Ilustrada. Revista artístico-literaria (9 de abril de 1911): Málaga, núm 82, p. 12. 